\title{
Exploring the "Age Question" in Research on Young Migrants in Southeast Asia
}

\author{
Roy Huijsmans ${ }^{1}$
}

Recent years have seen a blossoming of research on children and young people as migrants in the Southeast Asian context. This article takes the form of a stock-taking exercise of this rapidly growing new field of research. Yet, it also asks "what's new?" thereby contrasting and comparing contemporary scholarship with earlier work on young people and mobility in the region. The concept of age is central to the exercise of studying children and youth as a specific group of migrants, yet it is seldom subject to much conceptual scrutiny. Drawing on research from across the Southeast Asian region I illustrate how diverse conceptualizations of age can be recognized in various dimensions of the social process of migration and how these conceptual tools help illuminate migration as a relational and generational process.

Keywords: age; children; generation; intersectionality; migration; youth

\section{Introducing Child and Youth Migration in Southeast Asia}

Across Southeast Asia, children and young people have for a long time been affected by migration. This can, and has, taken various forms. Children are affected by migration when parent(s), sibling(s) or peers migrate even if they stay put themselves (Huijsmans, 2014a; Hoang and Yeoh, 2015). Children and young people may also become migrants themselves; they may be part of a family migration but they may also migrate unaccompanied by parents or adult guardians (Huijsmans, 2011: 1307-8).

This article takes the form of a stock-taking exercise, with a focus on research on children and young people who have migrated without their parents or adult guardian for purposes of work. Largely in response to a global interest in so-called "independent child migration" (UNDP, 2009: 59), there is now an emerging body of research on child and youth migrants in various Southeast Asian contexts. Much influenced by broader trends in social science research with children and young people, it is increasingly acknowledged that these young migrants are exercising agency in the process of migration (Beazley, 2015; Hoang and Yeoh, 2015). Over recent years, the research agenda, however, has moved beyond merely asserting agency (Capaldi, 2015). The emphasis is increasingly placed on accounting for the constrained, situated and relational manner in which agency needs be understood (Huijsmans, 2011). This includes questioning agency and vulnerability as oppositional concepts, as Mizen and OfosuKusi (2013) have argued based on research in Ghana and which is illustrated by Sallie Yea's (2016) work in relation to child migration in Vietnam.

Similar to migration for work involving adults, it is difficult to talk about migration for work in relation to children and young people in the Southeast Asian context in a general sense. The

\footnotetext{
${ }^{1}$ International Institute of Social Studies, Erasmus University Rotterdam, The Hague, the Netherlands. Email: huijsmans@iss.nl
}

An earlier version of this paper was presented at the $4^{\text {th }}$ Regional Conference of the Mahidol Migration Center (MMC) at the Institute for Population and Social Research (IPSR), Mahidol University, Salaya, Thailand, June 28-30, 2016. 
Southeast Asian socio-economic and political landscape is highly diverse, giving rise to very different migration projects in which the role of work features in a range of different ways. For example, many of the young migrants from Myanmar that have entered into Thailand are best described as "forced migrants" (Ball\& Moselle, 2016; Oh, 2012). For them, getting involved in migrant work in Thailand is thus part of the larger project of escaping conflict (Capaldi, 2016: 76-7). This contrasts with the young Cambodian migrants studied by Chivoin Peou (2016) who are involved in what is commonly known as rural-urban migration. Such temporary forms of labor migration may also take a cross-border form. For example, Maryann Bylander (2015) describes the young Cambodian migrants she worked with as involved in "cyclical" migration as the majority of the households had (young) family members working in Thailand for part of the year. Whereas the young migrants studied by Bylander and Peou had a reasonable degree of influence over their migration project, this was much less the case for some of the young Indonesian women and girls Atsushi Sano $(2012 ; 2016)$ worked with. Those who ended up in the Japanese sex sector especially were typically heavily debt-bonded (Sano, 2012: 30) and may best be described as victims of trafficking. Furthermore, Sallie Yea's (2016) work in Vietnam shows that forms of migration showing clear elements of human trafficking are not limited to sex work but were also observed among the young flower sellers and factory workers she studied in Ho Chi Minh City.

Despite these many differences in the migration projects children and young people get involved in, and the widely varied contexts in which these projects must be understood, what obviously connects these different studies is the shared focus on studying people who have become involved in migration at a relatively young age. Yet, it is precisely this "age question" that has to date received relatively little scholarly attention (exceptions include Hopkins and Pain, 2007; La Fontaine, 1978), especially in the context of migration and in Southeast Asia in particular. Building on a recent publication on theorizing age and generation in relation to development (Huijsmans, 2016a), I expand in this article on some concepts of age. More particularly, based on a deep reading of the literature on children and young people involved in migration in Southeast Asia, I seek to tease out how thinking critically and creatively about conceptualizations of age contributes to deepening our understanding of migration as situated in sets of generational relations.

The article is organized as follows. In the next section I briefly situate the contemporary phenomenon of child and youth migration in Southeast Asia in historical terms. I proceed by commenting on the knowledge about the scale and pattern of child and youth migration in Southeast Asia before moving on into teasing out how various concepts of age can be recognized in the existing scholarly literature on child and youth migration. I conclude by summing the analytical value of attending to the age question in migration.

\section{Migration by Young People: What's New?}

A separate literature on children and youth in migration might be relatively new, but the phenomenon certainly is not. One of the earliest publications on child migration coming out of the region that used the term is Agnes Camacho's work (1999) on child migrant domestic workers in Manila, the Philippines. Camacho's article was part of a special issue on "child labor". Importantly, her contribution was the only one in the special issue to discuss the connection between migration and children's work in an explicit manner. Nonetheless we can safely assume that this empirical connection was hardly new. A good part of the (street) working children were probably working away from home and arguably involved in a form 
of migration (Beazley, 2015: 297). Yet, this migration dimension seldom received specific attention as the dominant policy phrases of the time were "child labor" and "street children", and the issue of migration was not yet discussed as a children's issue.

For adolescents and youth, the story is slightly different. Young men especially were long involved in forms of movement without their parents or caregivers that were recognized in terms of migration. For example, Thomas Kirsch (1966) describes the phenomenon of pai thiaw ("going around") as a prominent channel of mobility among young Phu Thai men from northeastern Thailand. ${ }^{2}$ Writing in the 1960s, Kirsch (1966: 376) notes that the phenomenon of pai thiaw "has a long history within the Phu Thai region; indeed, the pattern seems to be shared with all Thai-speaking ethnic groups" (compare with Beazley, 2015: 301; Evrard, 2011). Moreover, his description of pai thiaw is worth quoting at length as it speaks to contemporary debates about youth labor migration in the region. Research shows that these migrations are highly youthful and aspirational and, thus, cannot be reduced to absolute poverty or just migration for work (e.g. Beazley, 2015; High, 2014; Mills; 1999):

The pai thiaw (or "going around") pattern: The Phu Thai share with the Central Thai and the Thai-Lao the pattern of "going around" in which young men, individually or in small groups, leave their home villages often going to urban areas or to the Central region to obtain wage labor of some sort, or occasionally to engage in intermittent, wandering trade. Although this pattern is closely tied to economic activities of one sort or another, it would be a mistake to view it in narrowly economic terms. In particular, young men do not leave their villages on such ventures simply because [of] the pressures of poverty. Poverty is more likely to force them to remain within their home village. This movement of individuals is tied more closely to ideas of "fun-seeking": - indeed, this is the literal Phu Thai equivalent of the Central Thai pai thiaw, i.e., pai din. (Kirsch, 1966: 375-6)

It is further worth noting that, as early as the 1960s, Kirsch observed that the age-old phenomenon of pai thiaw was gradually transforming from "relatively diffuse and unstructured" movements into patterned forms of mobility tied into capitalist development and urbanization (Kirsch, 1966: 376). These trends have only solidified over the 1980s and 1990s, much related to restructuring in the global economy resulting in a booming manufacturing industry in parts of Southeast Asia. While young men have remained involved in migration, most scholarly and policy attention over the 1980s and 1990s went out to young women, often adolescent girls, whose involvement in migration was a new phenomenon unfolding at a massive scale (Mills, 1999; Wolf, 1992). Much has been written about these socalled "factory daughters" 3 , yet seldom under the label of "child" or "youth migration" even though many of these young women got involved in migration during their teenage years.

Next to these changing gendered patterns shaping the migration of young people, its geography has also changed. Although, much, if not most, child and youth migration continues to take place within national borders (e.g. Camacho, 2010; Derks, 2008; Jones,

\footnotetext{
2 Kirsch describes the Phu Thai as a population that moved into present-day Thailand from what is now Laos at the time of the reign of Rama III (1788-1851) and that settled in four localities in the Northeast of present-day Thailand. Kirsch conducted his research with the Phu Thai population of Nong Suung in Ampur Kamcha-ee in Nakhon Phanom province (Kirsch, 1966: 371).

${ }^{3}$ Arguably to the extent that there is relatively little research on how gender works in relation to male youth in migration (Huijsmans, 2014b).
} 
Presler-Marshall \& Dang Bich, 2014; Peou, 2016; Rende Taylor, 2005) an increasing share takes a transnational form. For Thailand, by 2007 Simon Baker (2007: 175) even argued that, although the phenomenon of working children and youth may not have disappeared from Thai soil, it is increasingly foreign youngsters involved in this work (compare Bylander, 2015). ${ }^{4}$ Some of this cross-border migration for purposes of work is indeed long distance (Beazley, 2015: 303; Sano, 2012: 30), and it is these forms of migration that have attracted most scholarly and policy attention. Yet, some scholars (e.g. Huijsmans, 2012; Rungmanee, 2016a; Rungmanee, 2016b; Trần \& Huijsmans, 2014) have also pointed at the importance of less spectacular forms of cross-border movement: everyday cross-border mobility for purposes of work. This latter form of cross-border movement is relatively easily accessible to young people in particular, and probably widespread given existing cross-border networks and the considerable differences in levels of socio-economic development in the region.

\section{Figures, Patterns and Questions}

A technical paper produced by the Population Division of the United Nations (2011: iii) states that "in 2010, persons aged 15 to 24 accounted for almost 15 percent of all international migrants in development countries compared to 11 percent in developed countries." Such global figures are helpful despite their inevitable shortcomings. Most importantly, they put the spotlight on the fact that a considerable proportion of the global migrant population is youth. This is often not evident from existing migration data since most such data do not allow disaggregation by age.

Some limitations of such global data must also be recognized. First, this global figure on "youth migration" reduces young migrants to their demographic profile (migrant status and age in this case). As such, this figure has little to say about what are, arguably, more important variations: differences in social status. For example, it does not say whether these young migrants are part of family migration or have migrated without their parents or adult guardians. ${ }^{5}$ In addition, the figure also does not say anything about accumulated migration experiences. It is frequently assumed that figures about young migrants refer to young people's first-time involvement in migration. Yet, this need not be the case. And especially in relation to young people migrating without their parents or adult guardians attending to the absence or presence of previous migration experience(s) would allow differentiating qualitatively, and in a meaningful way, within the population of young migrants (Huijsmans, 2012). It must further be noted that such official data as is presented in the United Nations technical paper is limited to documented forms of migration. It is, thus, likely to be skewed towards children and young people who have migrated with their family, as these young migrants are more likely to have migrated through regular channels.

Getting an idea of the scale of children and youth migrating independently is notoriously difficult. For this, we are often limited to partial impressions such as data about "failed

\footnotetext{
4 There is an important demographic and socio-economic context to this observation. In Thailand, fertility levels are below replacement level whereas in neighboring countries (e.g. Cambodia, Laos, Myanmar) large family size is common, in rural areas in particular. In Thailand children also spend more years in school than is the norm in neighbouring countries, and rural Thai youth increasingly migrate for education to urban centres. In such a context, the continued demand for work done by the young is increasingly met by young migrants from neighboring countries.

${ }^{5}$ Note in this respect Shahin Yaqub's work (2009) on child migration in Argentina, Chili and South Africa: using census data (rather than household survey or migration data) he argues it is possible to identify whether children have migrated with or without their family.
} 
migrations" (i.e. young migrants who end up in shelters) (e.g. Huguet and Punpuing, 2005: 31); impressions from particular destination areas (e.g. Capaldi, 2015); or figures from sending areas (e.g. Rende Taylor, 2005; Huijsmans, 2012). These patchy impressions do not provide us with a complete overview. However, they do paint a picture. In line with the global data presented in the UN technical paper (United Nations, 2011), these glimpses suggest that, also in the context of Southeast Asia, migration appears located in the youth phase of the life course-involving relatively few very young people and also few older people. Indeed, in his review of migration in the context of development studies Arjan de Haan also observes that "labour migration is usually by young able-bodied people" (De Haan, 2006: 4).

\section{The Age Question in Migration}

As the previous section has illustrated, the concept of age is of central importance in debates about child and youth migration. It is thus surprising to note that "age" is seldom subject to much conceptual scrutiny in research on young people in migration. Moreover, even if conceptualized in its most straight-forward sense, chronologically, age-based categories may still be elusive, despite the clarity they convey. For example, in writing about the Thai context Jerrold Huguet and Sureeporn Punpuing (2005) define "children" (in line with the Thai minimum age of employment regulations) as young people below 15 years of age. In contrast, the UN technical paper referred to earlier defines children in line with the United Nations' Convention on the Rights of the Child as anyone below the age of 18 . This indeed means that a share of the "youth migrants" in the UN technical paper may also be referred to as "child migrants".

At one level, the age-brackets we attribute to particular life phases such as "childhood" or "youth" are just a matter of definition and therefore always somewhat arbitrary. Yet, this also has a discursive effect. The phenomenon of young people involved in migration defined as an issue of "child migration" triggers very different emotions and policy responses than if it were referred to as an issue of "youth migration". In broad terms, children involved in migration are often considered "out of place" and in this way easily become subject to interventions that seek to restore the "lost childhood". When referred to in terms of youth, their involvement in migration is much less a surprise. It can even be understood as positive youthful behavior, although there is also much concern about youth getting involved in risky activities.

The discussion above flags the importance of thinking about age, the various ways in which we conceptualize it, how this shapes migration as a social phenomenon as well as how such age-based frames affect the way we think about young migrants. Drawing on a discussion started in the introductory chapter to Generationing Development (Huijsmans, 2016a) I proceed by elaborating on three different concepts of age: chronological age, relative age and social age, and how they relate to migration.

\section{Chronological Age}

The age of majority matters for purposes of migration because it generally determines the moment at which a person is entitled to seek admission into another country on his or her own right, without being necessarily a dependant of someone else. In addition, for certain 
categories of migrants, countries of destination impose restrictions based on age. For instance, countries allowing family reunification often establish a maximum age for children to be admitted as dependants and that age is not necessarily the age of majority. (United Nations, 2011: 3)

The excerpt below is illustrative of how a particular concept of age, chronological age, is "made important", to use Cheryl Laz's words (Laz, 1998: 92, original emphasis), in the context of international migration. It is on the basis of chronological age that young migrants may be classified as "child migrants" (UNDP, 2009: 59) in case they are younger than 18 years of age. It is also on the basis of chronological age that such child migrants have certain entitlements but are also subject to special protective measures that might mean they are excluded from certain forms of migrant work (on the basis of minimum age regulations) or from certain channels of migration altogether. ${ }^{6}$ The latter can be illustrated by efforts by Thai border officials in early 2015 to combat human trafficking by banning young Lao nationals from entering Thailand in case they are travelling alone and are younger than 18 years of age ("Lao Teens Banned", 2015).

Laz (1998) calls for a sociology of age, to unravel why chronological age as a particular conceptualization of age has become hegemonic, and how this matters. In the context of migration, the appeal of chronological age is found in its universalizing potential and the simplification it achieves. Cross-border migration is an international affair and for this reason it is tempting to think that governing it effectively would require measures that are not context specific, such as chronological age. Moreover, James Scott adds further that states often resort to forms of state-simplifications, such as biographical data, in order to make an otherwise highly heterogeneous population "legible" - a necessary requirement to govern (Scott, 1998). It is based on such premises that chronological age has become a prime measure in a wide range of policies and regulations, including those concerning migration, and is thus made important.

Sallie Yea's (2016) critical evaluation of a "raid and rescue" approach to Vietnamese migrant children working in Ho Chi Minh City suggests however, that successful interventions are, perhaps, precisely about diverging from the "age-normativity" (Huijsmans, 2015) set out in (inter)national conventions and policies concerning children and young people. Unlike most raid and rescue approaches, the case studied by Yea stands out in terms of its sensitivity, embeddedness and its participatory approach to anti-trafficking. The Hue based program she studied is doing, what Yea (2016: 5) describes as "appropriate removal and support". The rescue only takes place with the consent of parents and (where contactable) children. ${ }^{7}$ This means making parents aware of the working conditions of their children in Ho Chi Minh City and involving them, and the children concerned, in working out a post-trafficking plan. Unlike the common model, such a post-trafficking plan never includes a shelter or another form of formal rehabilitation but is geared towards "going home, moving on" (Yea, 2016: 12). While returning to school is presented as an option, an appropriate post-trafficking plan could also include "supporting the child's right to nonexploitative work" (Yea, 2016: 16).

\footnotetext{
${ }^{6}$ Note Bourdillon, White and Myers' (2009) important critique of minimum age regulations.

${ }^{7}$ Note too that the funder (United Nations Inter Agency Project (UNIAP)) also requires that the Vietnamese police "must be in attendance during the rescue" (Yea, 2016: 10).
} 
Yea's case study is a rare account of success in a critical anti-trafficking literature that is characterized by analyses of failed and problematic interventions. Yea argues that the key to this success lies in the program's "partial and incomplete adoption of global child rights discourses and anti-trafficking responses" (Yea, 2016: 16). More specifically, the program delineates from an age-normativity in which childhood is strictly defined on the basis of chronological age and disassociated from the world of work. Thereby, this program allows for different understandings of age to inform social interventions.

Table 1 lists some conceptualizations of age. Although the idea of "age" is frequently equated with chronological age, Table 1 shows that the dominance of chronological age is mostly limited to the sphere of policies and regulations. In the everyday, alternative conceptualizations of age might well be more meaningful conceptual tools. Yea's example further illustrates that even in domains where chronological age is dominant (i.e. social interventions) there may still be room for alternative understandings of age to meaningfully contribute to practice (Clark-Kazak, 2016).

Table 1: Concepts of age

\begin{tabular}{|c|c|c|}
\hline Concept of age & Definition & Locating its analytical value \\
\hline Chronological age & $\begin{array}{l}\text { "the figure identifying the number of } \\
\text { (Gregorian) calendar years that have } \\
\text { passed since birth" (Huijsmans, 2016b: 8) }\end{array}$ & $\begin{array}{l}\text { In relation to policies and } \\
\text { regulations }\end{array}$ \\
\hline Social age & $\begin{array}{l}\text { "the socially constructed meanings applied } \\
\text { to physical development and roles } \\
\text { attributed to infants, children, young } \\
\text { people, adults and elders, as well as their } \\
\text { intra-and inter-generational } \\
\text { relationships" (Clark-Kazak, 2009: 1310) }\end{array}$ & $\begin{array}{l}\text { In relation to the social organization } \\
\text { of everyday life }\end{array}$ \\
\hline Relative age & $\begin{array}{l}\text { "Whether one is older/younger than } \\
\text { someone else (mostly on the basis of } \\
\text { chronological age) and how this informs } \\
\text { everyday social interactions" (Huijsmans, } \\
\text { 2014a) }\end{array}$ & $\begin{array}{l}\text { In relation to direct interactions in } \\
\text { everyday social life }\end{array}$ \\
\hline
\end{tabular}

\section{Social Age}

In much of Southeast Asia, the importance of chronological age is limited to so-called state spaces such as schools, documents, official border crossing posts and health centers. Still, concepts like "child", "youth", and "adolescent" do feature in everyday speech, as well as various other more localized categories of human development (Huijsmans, 2010: 123-5). The important point is that such social age categories often differ from the chronological age categories carrying the same name. First, while social age categories like "child" and "youth" obviously relate to chronological age, they are not defined by it. Young people's appearance and performance are ultimately more important. It is such social facts that render someone a youth or a child. This also means that social age categories are necessarily more fluid and flexible than chronological age categories.

Migration is one such phenomenon where different generational modalities come to collide. For example, through involvement in migration young people can establish themselves more firmly as youth (as opposed to being seen as dependent children). This is well illustrated by 
this quote from an adolescent male in a focus group discussion among Thai youth on how their involvement in migration changed their generational position:

It's very different. They [my parents] listen to everything I say now. When I didn't earn money, it was like blowing in the wind when I talked. (Thai youth focus group participant as cited in Soonthorndhada et al., 2005: 116)

It is not fully clear whether this quote comes from a young man below or above 18 years of age. What is clear however, is that would this young man be of minority age and get involved in cross-border migration he would be considered a "child migrant" despite being involved in a social practice that affirms his youthfulness in terms of social age. The tension between different concepts of age not only shapes migration as a social practice, it also affects the interpretation of the phenomenon by so-called experts. This is evident from the following quote from an NGO staff member interviewed by Mark Capaldi as part of his Thailand based research on independent child migration:

Basically, the CRC (Convention of the Rights of the Child) defines the legal age - it doesn't take into consideration the child's maturity. The legal age is the cut-off of services for the accountability of the State. The CRC has an assumption of immaturity, but different cultures assess maturity in different ways. I think independent child migration is a positive expression of the human spirit and youth. (NGO staff member as cited in Capaldi, 2015:16)

This excerpt illustrates very well how professionals are often biased to think in terms of professional categories that draw on the notion of chronological age. Yet, it also shows that such professional knowledge has seldom fully muted alternative ways of viewing social reality (for a similar example from the Lao context, see: Molland, 2012: 208). In this case, the social age category of "youth" is mobilized. From this conceptual vantage point, the involvement of adolescents in migration is not so much an anomaly, but can even be viewed as "a positive expression" as the excerpt illustrates.

The working of social age can also be observed at the migration destination. Pilapa Esara's (2004) work shows very clearly that for young female Thai migrants in Bangkok, the shift in social status from "migrant daughter" to "migrant mother" following marriage and motherhood is far more profound than reaching the chronological age of majority. She further argues that Bangkok employers prefer hiring young single women "below the age of twentyfive, who they believe are less likely to quit or ask for time off due to family concerns such as pregnancy" (Esara, 2004: 203). As Kerry Richter's (1996: 336) work in the context of Bangkok shows, this might lead some young women to perform the social age of youth by presenting themselves to urban employers as young female workers without family obligations by leaving their children behind in their home community. ${ }^{8}$

\section{Relative Age}

The idea of relative age is perhaps most overlooked in research on children and youth in relation to migration. Particularly in Southeast Asia this is somewhat surprising. In a context where various language systems require differentiation in terms of address and reference,

8 Of course, here the performance of social age is also much related to the challenge of social reproduction (Huijsmans, 2013). 
amongst other things, based on age (Enfield, 2007; Szymańska-Matusiewicz, 2014) most researchers are confronted with the importance of relative age in the process of doing research. Thus, it is strange to see that this awareness rarely informs the analysis in work on child and youth migration.

As I have argued in my work on migration decision making at the level of the household in a sending area in rural Laos (Huijsmans, 2014a), relations of relative seniority between young people within the household help explain why some young people become involved in migration while others stay. The conceptual purchase of the notion of relative age is of course greater in contexts of above-replacement level fertility and complex household structures than it would be in the one-or-two child households that are rapidly becoming the norm in much of Thailand and Vietnam.

Next to the household, relative age also matters at the migration destination. Relative age might further reinforce migrant subordination for those young migrants who are the youngest at the place of work. In addition, relative age might also matter because of its absence from certain social interactions. This point can be illustrated by turning to the work of Raya Muttarak (2004) on domestic workers and their employers in Bangkok. She observes that "almost all employers address their domestic workers merely by name, regardless of age" and that the same is true for the children of many employers (Muttarak, 2004: 515). In a context in which terms of address indicate relative seniority or juniority, the erasure of such relative agebased differences effectively serves to leave unchallenged the power differentials rooted in social class that structure the domestic domain.

\section{Conclusion}

Since the turn of the millennium, research on children and youth migrating for purposes of work without their parents or caregivers has grown into what is now a sizeable body of literature. Much of this literature is based on research conducted in Africa (Hashim and Thorsen, 2011; Howard, 2014) and Latin America (Bastia, 2005; Punch, 2007). Initially there was only relatively little work coming out of Southeast Asia. This state of affairs has changed considerable over recent years, and part of the aims of the article was to conduct a stock-taking exercise of this new research coming from the Southeast Asian region.

This blossoming of current research on children and youth as migrants in Southeast Asia does not mean that the phenomenon is new. As I have argued, children and young people have long been involved in migration in the Southeast Asian context although the phenomenon was seldom referred to in these terms. At the same time, some important historical changes must be noted. First, migration was historically largely limited to male youth, recent decades have seen, however, the large scale involvement of girls and female youth in migration. In addition, contemporary migration movements have increasingly become shaped by capitalist development, urbanization, and also by differences in fertility regimes across the Southeast Asian landscape.

I have further argued that the literature on young people migrating for work in Southeast Asia is hugely diverse. It comprises a range of different migration projects, situated in an array of different migratory contexts. Still, some commonalities may also be observed. Although Sallie Yea (2016: 9) notes that the youngest migrant flower sellers working on the streets of Ho Chi Minh City are nine or 10 years of age, young people mostly become involved in migration in 
their second decade of life. For example, Maryann Bylander (2015: 1129) notes that from the age of 14 or 15 it is not uncommon to see young Cambodians leaving for work to Thailand.

It is precisely in this second decade of life that referring to young people simply as "children" in line with (inter)national regulations captures only part of the story. Migration processes involving young people are situated in different generational modalities that revolve around different concepts of age. Age is conceptualized differently in the migration regulations governing cross-border mobility, than it is in the context of everyday village life, or within the intimate space of the household or the migrant work place. Drawing on research examples from across Southeast Asia I have illustrated how age works slightly differently in all these spaces, and how at times different concepts of age come to collide.

Since age is fundamental to the very idea of studying children and young people as a specific migrant population, is it important to ask how we understand age precisely? How, in its different forms, does it play out in the social process of migration? And what sort of insights does such an age-lens offer to research, policy and practice. Most importantly, conceptualizing age is crucial for coming to a more relational understanding of young people in migration. That is, how, on the basis of their age-position are young people situated in diverse migratory contexts? Finally, it is also important to note that age never works in isolation. It always interacts with other social relations such as gender, ethnicity, sexuality, religion, class, etc. Yet, the abstract measure of the chronological conceptualization of age easily blurs the intersectional dimension of age. Examples presented in this article of, for example, social age through the work of Kerry Richter (1996) and relative age through the work of Raya Muttarak (2004), have shown that alternative conceptualizations of age are well-suited for illuminating how age always intersects with other social characteristics.

\section{References}

Baker, S. (2007). 'Child labour' and child prostitution in Thailand: Changing realities. Bangkok: White Lotus.

Ball, J. \& S. Moselle (2016). Forced migrant youth's identity development and agency in resettlement decision-making: Liminal life on the Myanmar-Thailand border. Migration, Mobility, $\mathcal{E}$ Displacement 2(2): 110-125. doi: $10.18357 / \mathrm{mmd} 22201616157$

Bastia, T. (2005). Child trafficking or teenage migration? Bolivian migrants in Argentina. International Migration 43(4): 57-87. doi: 10.1111/j.1468-2435.2005.00333.x

Beazley, H. (2015). Multiple identities, multiple realities: Children who migrate independently for work in Southeast Asia. Children's Geographies 13(3): 296-309. doi: $10.1080 / 14733285.2015 .972620$

Bourdillon, M.F.C., B. White \& W.E. Myers (2009). Re-assessing minimum age standards for children's work. International Journal of Sociology and Social Policy 29(3/4). doi: 10.1108/01443330910947480

Bylander, M. (2015). Contested mobilities: Gendered migration pressures among Cambodian youth. Gender, Place and Culture 22(8): 1124-1140. doi: 10.1080/0966369X.2014.939154

Camacho, A.Z.V. (1999). Family, child labour and migration: Child domestic workers in metro Manila. Childhood 6(1): 57-73. doi: 10.1177/0907568299006001005

Camacho, A.Z.V. (2010). Children and migration: Understanding the migration experiences of child domestic workers in the Philippines. In. M. Liebel \& R. Lutz (Eds.) Sozialarbeit des Südens, Band 3: Kindheiten und Kinderrechte (pp. 127-160). Oldenburg, Paolo Freire Verlag.

Capaldi, M.P. (2015). Rethinking independent child migration in Thailand: Victims of exploitation or competent agents? Journal of Population and Social Studies 23(1): 16-32. doi: $10.14456 / j p s s .2015 .10$

Capaldi, M.P. (2016). The child's journey in search of rights: Assessing the construction of vulnerability in independent child migration in Thailand. (Unpublished doctoral dissertation). Human Rights and Peace Studies, Mahidol University, Nakhon Pathom, Thailand. 
Clark-Kazak, C. (2016). Mainstreaming social age in the sustainable development goals: Progress, pitfalls and prospects. In. R. Huijsmans (Ed.) Generationing Development: A relational approach to children, youth and development (pp. 103-123). London, New York: Palgrave Macmillan.

Clark-Kazak, C.R. (2009). Towards a working definition and application of social age in international development studies.' Journal of International Development 45(8): 1307-1324. doi: $10.1080 / 00220380902862952$

De Haan, A. (2006). Migration in the development studies literature: Has it come out of its marginality? (Research Paper No. 2006/19). Helsinki: UNU-WIDER. Retrieved from http:// www.rrojasdatabank.info/rp2006-19.pdf

Derks, A. (2008). Khmer women on the move: Exploring work and life in urban Cambodia. Honolulu: University of Hawai'i Press.

Enfield, N.J. (2007). Meaning of the unmarked: How 'default' person reference does more than just refer. In N.J. Enfield and T. Stivers (Eds.), Person reference in interaction: Linguistic, cultural and social perspectives (pp. 97-120). Cambridge: Cambridge University Press.

Esara, P. (2004). "Women will keep the household": The mediation of work and family by female labor migrants in Bangkok. Critical Asian Studies 36(2): 199-216. doi: 10.1080/14672710410001676034

Evrard, O. (2011). Oral histories of livelihoods and migration under socialism and post-socialism among the Khmu of northern Laos. In J. Michaud and T. Forsyth (Eds.), Moving mountains: Highland identities and livelihoods in post-socialist China, Vietnam and Laos (pp. 76-99). Vancouver: UBC Press.

Hashim, I. \& D. Thorsen (2011). Child migration in Africa. Uppsala \& London, New York: The Nordic Africa Institute \& Zed Books.

High, H. (2014). Fields of desire: Poverty and policy in Laos. Singapore: NUS Press.

Hoang, L.A. \& Yeoh, B.S.A. (2015). Children's agency and its contradictions in the context of transnational labour migration from Vietnam. Global Networks 15(2): 180-197. doi: 10.1111/glob.12057

Hopkins, P. \& R. Pain (2007). Geographies of age: Thinking relationally. Area 39(3): 287-294. doi: 10.1111/i.1475-4762.2007.00750.x

Howard, N. (2014). Teenage labor migration and antitrafficking policy in West Africa. The ANNALS of the American Academy of Political and Social Science 653(1): 124-140. doi: 10.1177/0002716213519242

Huguet, J.W. \& S. Punpuing (2005). Child migrants and children of migrants in Thailand. Asia Pacific Population Journal 20(3): 123-142.

Huijsmans, R. (2011). Child migration and questions of agency. Development $\mathcal{E}$ Change 42(5): 1307-1321. doi: $10.1111 /$ j.1467-7660.2011.01729.x

Huijsmans, R. (2012). Beyond compartmentalization: A relational approach towards agency and vulnerability of young migrants. New Directions for Child and Adolescent Development (136): 29-45. doi: $10.1002 /$ cad. 20009

Huijsmans, R. (2013). 'Doing gendered age': Older mothers and migrant daughters negotiating care work in rural Lao PDR and Thailand. Third World Quarterly 34(10): 1896-1910.

Huijsmans, R. (2014a). Becoming a young migrant or stayer seen through the lens of 'householding': Households 'in flux' and the intersection of relations of gender and seniority. Geoforum 51: 294304. doi: $10.1016 /$ j.geoforum.2012.11.007

Huijsmans, R. (2014b). Gender, masculinity, and safety in the changing Lao-Thai migration landscape. In T-D. Truong, D. Gasper, J. Handmaker and S.I. Bergh (Eds.), Migration, gender and social justice: Perspectives on human security (pp. 333-349). Heidelberg, New York, Dordrecht, London: Springer.

Huijsmans, R. (2015). 'Children and Young People in Migration: A relational approach' in. C. Ní Laoire, A. White \& T. Skelton (eds.) Movement, Mobilities and Journeys. Singapore, Springer. 6.

Huijsmans, R. (Ed.) (2016a). Generationing development: A relational approach to children, youth and development. London, New York: Palgrave Macmillan.

Huijsmans, R. (2016b). Generationing development: An introduction. In R. Huijsmans (Ed.), Generationing development: A relational approach to children, youth and development (pp. 1-31). London, New York, Palgrave Macmillan.

Huijsmans, R.B.C. (2010). Migrating children, households, and the post-socialist state: An ethnographic study of migration and non-migration by children and youth in an ethnic Lao village. (Unpublished doctoral dissertation). Department of Geography, Durham University, Durham, U.K. 
Jones, N., E., Presler-Marshall, E. \& T. Dang Bich (2014). Falling between the cracks: How poverty and migration are resulting in inadequate care for children living in Viet Nam's Mekong Delta. London, Overseas Development Institute.

Kirsch, A.T. (1966). Development and mobility among the Phu Thai of Northeast Thailand. Asian Survey 6: 370-378. doi:10.1525/as.1966.6.7.01p01873

La Fontaine, J.S. (Ed.) (1978). Sex and age as principles of social differentiation. London, New York, San Francisco: Academic Press.

Lao teens banned from entering Thailand. (2015, September 25). The Nation. Retrieved from http:// www.nationmultimedia.com/news/national/aec/30254803

Laz, C. (1998). Act your age. Sociological Forum 13(1): 85-113. doi: 10.1023/A:1022160015408

Mills, M.B. (1999). Thai women in the global labor force: Consuming desires, contested selves. New Brunswick, New Jersey, London: Rutgers University Press.

Mizen, P. \& Ofosu-Kusi, Y. (2013). Agency as vulnerability: Accounting for children's movement to the streets of Accra. The Sociological Review 61(2): 363-382. doi: 10.1111/1467-954X.12021

Molland, S. (2012). The perfect business? Anti-trafficking and the sex trade along the Mekong. Honolulu: University of Hawai'i Press.

Muttarak, R. (2004). Domestic service in Thailand: Reflection of conflicts in gender, class and ethnicity. Journal of Southeast Asian Studies 35(3): 503-529. doi: 10.1017/S0022463404000256

Oh, S.A. (2012). Photofriend: Creating visual ethnography with refugee children. Area 44(3): 382-388. doi: $10.1111 /$ j.1475-4762.2012.01111.x

Peou, C. (2016). Negotiating rural-urban transformation and life course fluidity: Rural young people and urban sojourn in contemporary Cambodia. Journal of Rural Studies 44: 177-186. doi:10.1016/j.jrurstud.2016.02.002

Punch, S. (2007). Negotiating migrant identities: Young people in Bolivia and Argentina. Children's Geographies 5(1): 95-112. doi: 10.1080/14733280601108213

Rende Taylor, L. (2005). Dangerous trade-offs: The behavioural ecology of child labor and prostitution in rural northern Thailand. Current Anthropology 46(3): 411-431. doi: 10.1086/430079

Richter, K. (1996). Living separately as a child-care strategy: Implications for women's work and family in urban Thailand. Journal of Marriage and Family 58(2): 327-339. doi: 10.2307/353499

Rungmanee, S. (2016a). Illegal but licit: Migrant mobility and the negotiation of legality in the northeast Thai-Lao borderlands. Asia Pacific Viewpoint 57(2): 221-231. doi: 10.1111/apv.12124

Rungmanee, S. (2016b). Unravelling the dynamics of border crossing and rural-to-rural-to-urban mobility in the Northeastern Thai-Lao borderlands. Population, Space and Place 22(7): 693-704. doi: 10.1002/psp.1989

Sano, A. (2012). Agency and resilience in the sex trade: Adolescent girls in rural Indramayu. The Asia Pacific Journal of Anthropology 13(1): 21-35. 10.1080/14442213.2011.636064

Sano, A. (2016). Victimhood and agency in the sex trade: Experiences and perceptions of teenage girls in rural west Java. (Unpublished doctoral dissertation). International Institute of Social Studies, Erasmus University Rotterdam, The Hague.

Scott, J.C. (1998). Seeing like a state: How certain schemes to improve the human condition have failed. New Haven, London: Yale University Press.

Soonthorndhada, A., Kittisuksathit, S., Punpuing, S., Varangrat, A., Malhotra, A., Curran, S.R. \& Martin, S.B. (2005). Youth at odds: Thai youth's precarious futures in a globalized world. Nakhon Pathom: Institute for Population and Social Research, Mahidol University.

Szymańska-Matusiewicz, G. (2014). The researcher as 'older sister', 'younger sister' and 'niece': Playing the roles defined by the Vietnamese pronominal reference system. Qualitative Research 14(1): 95111. doi: $10.1177 / 1468794112465636$

Trần, T.H.L. \& R. Huijsmans (2014). Experiencing the state and negotiating belonging in Zomia: Pa Koh and Bru-Van Kieu ethnic minority youth in a Lao-Vietnamese borderland. In S. Spyrou and M. Christou (Eds.), Children and borders (pp. 27-46). Basingstoke: Palgrave MacMillan.

United Nations Development Program (UNDP). (2009). Human development report 2009. Overcoming barriers: Human mobility and development. New York: United Nations Development Program. Retrieved from http://hdr.undp.org/sites/default/files/reports/269/hdr_2009_en_complete.pdf

United Nations (2011). International migration in a globalizing world: The role of youth. Technical Paper No 2011/1. New York: Population Division, United Nations. Retrieved from http://www.un.org/esa/population/publications/technicalpapers/TP2011-1.pdf 
Wolf, D.1. (1992). Factory daughters: Gender, household dynamics, and rural industrialization in Java. Berkeley and Los Angeles: University of California Press.

Yaqub, S. (2009). Child migrants with and without parents: Census-based estimates of scale and characteristics in Argentina, Chile and South Africa. Innocenti Discussion Paper No. IDP 200902. Florence, UNICEF, Innocenti Research Centre.

Yea, S. (2016). Vietnamese children trafficked for forced labour to Ho Chi Minh City, Vietnam: Exit, return and reintegration. In. C. Ni Laoire, A. White and T. Skelton (Eds.), Movement, mobilities, and journeys (pp. 1-18). Singapore: Springer Singapore. 